\title{
A Critical Sociocultural Perspective on ACADEMic Literacies in Latin America
}

\author{
UNA PERSPECTIVA SOCIOCULTURAL CRÍTICA A LAS LITERACIDADES \\ aCADÉmicas en América Latina \\ UNE APPROCHE SOCIOCULTURELLE CRITIQUE DES LITTÉRACITÉS \\ ACADÉMIQUES À L'AMÉRIQUE LATINE
}

\author{
Lina Trigos-Carrillo \\ Ph. D. in Learning, Teaching and \\ Curriculum (Reading/Literacy \\ Education); University of Missouri; \\ Columbia. Post-doctoral research \\ fellow; University of Missouri, Co- \\ lumbia, Missouri, USA. \\ Via Canelón, conjunto Bosque \\ Canelo, torre 2, apto. 208, Cajicá, \\ Colombia. \\ trigoscarrillol@missouri.edu \\ https://orcid. \\ org/0000-0003-2297-3906
}

\begin{abstract}
In this editorial, the author reflects on the state of research on academic literacies in Latin American higher education. To this end, the author presents a description of the context of higher education in Latin America and an analysis of literature on academic literacies in the region through the lenses of three models: the study skills model, the academic socialization model, and the critical sociocultural model. Based on this analysis, the author argues that a critical sociocultural perspective is emerging in Latin America, which considers academic literacies as social practices embedded in systems of power. This transition to a critical sociocultural perspective is important and timely because it challenges deficit views of students, and it addresses issues of power, identity, representation, and authority. The author invites Latin American scholars to consider the implications of a critical sociocultural perspective on academic literacies and the possibilities it offers for understanding how youth interact with literacy in a region where education often reinforces deep inequalities.
\end{abstract}

Keywords: Academic literacies; Latin America; higher education; critical sociocultural perspective; literacy.

\section{RESUMEN}

En esta editorial, la autora reflexiona sobre el estado de la investigación en literacidades académicas en la educación superior latinoamericana. Con este fin, la autora presenta una descripción del contexto de la educación superior en América Latina, y analiza la literatura sobre literacidades académicas en la región bajo los lentes de tres modelos: el modelo de habilidades de estudio, el modelo de socialización académica y el modelo sociocultural crítico. Con base en este análisis, la autora determina la aparición de una perspectiva crítica en América Latina, que considera las literacidades académicas como prácticas sociales insertas en sistemas de poder. Este viraje hacia una perspectiva sociocultural crítica es importante y oportuno, porque cuestiona las opiniones deficitarias de los estudiantes, e incluye aspectos de poder, identidad, representación y autoridad. La autora invita a los académicos latinoamericanos a considerar las implicaciones de una perspectiva sociocultural crítica hacia las literacidades académicas y las posibilidades que ofrece para en-

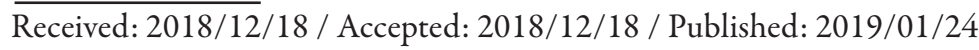

DOI: $10.17533 /$ udea.ikala.v24n01a10 
tender cómo interactúan los jóvenes con la literacidad en una región donde las más de las veces la educación refuerza profundas desigualdades.

Palabras claves: literacidades académicas; América Latina; educación superior; perspectiva sociocultural crítica; literacidad.

\section{Résumé}

Dans cet éditorial, l'auteur réfléchit sur l'état de la recherche sur les littéracités académiques dans l'enseignement supérieur en Amérique latine. Dans ce but, l'auteur décrit ce contexte et analyse le cadre théorique à propos des littéracités académiques dans la région en s'appuyant sur trois modèles: le modèle des compétences d'étude, le modèle de socialisation académique, et le modèle socioculturel critique. D'après cette analyse, l'auteur établit l'apparition d'une approche critique en Amérique latine. Dans cette approche, les littéracités académiques sont définies comme des pratiques sociales insérées dans des systèmes de pouvoir. Ce tournant vers une approche socioculturelle critique est important et opportun, car il met en question les jugements déficitaires des étudiants, en incluant des questions de pouvoir, identité, représentation et autorité. L'auteur invite les érudits latino-américains à considérer les enjeux d'une approche socioculturelle critique dans les littéracités académiques et les outils qu'elle offre visant à comprendre comment la jeunesse interagit avec la littéracité dans une région où l'éducation renforce, la plupart des fois, des inégalités profondes.

Mots-clés : littéracités académiques ; Amérique latine ; études universitaires supérieures; approche socioculturelle critique ; littéracité. 


\section{Introduction}

The study of academic reading and writing in Latin America has boomed since the end of the $20^{\text {th }}$ century, when several scholars started to investigate how students learned to read and write in formal academic settings. At the beginning, most of these approaches treated reading and writing as cognitive skills, and academic texts as communicative outcomes. However, more recent approaches have incorporated the concept of academic literacies, which was developed to study literacies in academic contexts occurring mostly in higher education (Lea \& Street, 2006). In contrast to traditional conceptions of reading and writing, the academic literacies approach is characterized by the recognition of multiple literacies, an insistence on the ideological character of literacies, an emphasis on social practices over texts, the recognition of difference, and a particular attention to the relationships of power, authority, meaning making, and identity that are implicit in the use of literacy practices within specific institutional settings (Horner, 2013; Lea \& Street, 2006). This edition of Íkala constitutes a reflection on this stage in literacy research as it includes articles about academic literacies in relation to issues of authority, representation, belief systems, rhetorical moves, and social norms and practices.

Before presenting a brief contextual description of Latin American higher education and the analysis of academic literacies in the region, I will offer some preliminary observations about the topic. First, the term academic literacies has different translations in Spanish. The expression literacidades académicas is a neologism that has been incorporated into the literature to refer to an ideological approach to literacy (Mora, 2012; Trigos-Carrillo \& Rogers, 2017). This expression offers an alternative to traditional translations of the word literacy such as alfabetismo or alfabetización, which are semantically restrictive because, on one side, alfabetismo refers to basic knowledge about reading and writing, and on the other, the two terms derive from the word alphabet, which is associated with both the process of language codification and the act of decoding words in reading and writing. The conceptualization implied in these terms assumes that, once people have sufficiently learned to read and write, they will not need to develop other literacies for different domains of life. I therefore prefer the use of literacidad académica in Spanish. In Portuguese, the word alfabetização is used to refer to alphabetization, while the neologism letramento refers to literacy. Although the word letramento has been more accepted than literacidad in Spanish, the uses and meanings of this neologism are still under debate (Marinho, 2013).

Second, there are limited resources available for accessing existing research in Spanish and Portuguese. Databases in the field of education such as JSTOR, SpringerLink, ProQuest Dissertations and Theses, Academic Search Complete, and Scopus mainly index articles written in English. In comparison, databases in the field of education in Spanish are scarce. To circumvent these limitations, I used additional tools and strategies to identify the relevant literature. These included contacting some of the region's experts, scholars and associations that specialize in academic literacies; refining the variety of search terms in English and Spanish; using other databases such as Redalyc, SciELO, and the English, Spanish, and Portuguese versions of Google Scholar; and expanding the range of available online research examined to include such sources as conference proceedings and reports from international organizations. The organizations and entities whose work I consulted included the Organisation for Economic Co-operation and Development (OECD); the United Nations Educational, Scientific and Cultural Organization (UNESCO); the International Institute for Higher Education in Latin America and the Caribbean (Instituto Internacional de Educación Superior para América Latina y el Caribe, or IESALC); the United Nations Economic Commission for Latin America and the Caribbean (ECLAC, Comisión 
Económica para América Latina y el Caribe or CEPAL in Spanish); and relevant national education ministries.

To broaden my searches in Spanish, I used the following expressions: alfabetización académica, lectura y escritura, competencia oral y escrita, escritura en universitarios, and literacidad académica combined with the terms educación superior and/ or educación postsecundaria o terciaria. I also included a wider variety of word forms, such as conjugated verbs and their infinitives lee and leer (to read) and escribe and escribir (to write). In Portuguese, I looked for the expression letramento acadêmico. In English, the search terms were academic literacies, college reading and writing, and college literacy combined with the terms higher education and Latin America. I also conducted searches by the names of authors, particularly those recognized as experts in the field.

In this editorial, I will present a brief context of higher education in Latin America followed by an analysis of the research on academic literacies through the lenses of three theoretical models: the study skills model, the academic socialization model, and the critical sociocultural model (Lea \& Street, 2006). Finally, I will offer some insights on a critical sociocultural approach to academic literacies and some implications for the Latin American context. Ultimately, I argue that more research is needed in the field of literacy studies that involves the conception of literacy as a social practice in the region.

\section{The Context of Higher Education in Latin America}

Higher education faces several challenges in Latin America, such as access inequality, low enrollment rates, a mismatch between specialties offered and the needs of the labor market, and low graduation rates (Dudziak, 2007; Holm-Nielsen, Thorn, Brunner \& Balán, 2005). Due to inequalities in access to education, many students do not receive sufficient preparation in academic literacies to succeed in higher education (Holm-Nielsen, et al., 2005). Furthermore, universities often reproduce access inequalities by favoring students who have had the privilege of attending private schools.

Latin America is a region that includes the countries located in Central and South America as well as Mexico (in North America) and the Caribbean. The countries of this region are usually grouped together because they share a similar history and culture, even though its population is multilingual, multiethnic and pluricultural (CEPAL, 2000). In this text, when referring to Latin America I include Brazil and the Spanish speaking countries, but I exclude the Caribbean.

The standard language of the region is Spanish with the exception of Brazil, whose standard language is Portuguese. Formal education is broadly instructed in the standard languages; although, according to the Archive of Indigenous Languages of Latin America (AILLA), there are over 56 language families and over 73 language isolates currently spoken in the region (AILLA, 2014). For example, in Colombia nearly 65 languages are active; in Peru, 60 languages; in Mexico, 50; and in Bolivia, 30. Some countries of the region such as Bolivia, Guatemala, Peru and Ecuador have an indigenous population of more than $30 \%$ (Lee, 2010). There are also important Afro-descendant populations in several countries, especially in Brazil.

In 2013, the youth population (people from 15 to 24 years old) was more than 108 million in Latin America (CEPAL, 2014), the majority of whom lived in urban areas. Latin American young people face deep socioeconomic and political problems. One of the main problems is inequality. For instance, there is "a small proportion of youth emerging as highly educated knowledge workers with considerable expendable income, and a large proportion of working-class and poor youth relegated to low-paying, informal work or joblessness" (Cunningham, McGinnis, García, Verdú, \& Dorte, 2008, p. 8). Youth employment statistics are alarming: one in four young people in Latin 
America are jobless, and six out of 10 employed youth have an informal job.

Regarding education, of the total youth population, nearly $35 \%$ only studies, $33 \%$ only works, nearly $12 \%$ works and studies at the same time, and one out of five young people neither studies nor works. In addition, there are gender inequalities: According to the United Nations International Labour Organization (Organización Internacional del Trabajo or OIT in Spanish), among 15- to 24-year-olds, $20 \%$ of the women is in charge of domestic house work, while only $2 \%$ of male youth do this kind of work (OIT, 2013). While women are a majority in literacy programs and centers, men predominate "in higher educational levels, vocational and professional training programs, ICT-related training and utilization, and non-formal educational opportunities that go beyond simple tasks and the domestic world" (Torres, 2009, p. 7).

After 1960, Latin America experienced one important shift in youth literacy with the beginning of popular education and non-formal education based on Paulo Freire's work. Most of the programs during this time were aimed at eradicating illiteracy in the sense of basic reading and writing skills. Nowadays, the region has youth basic literacy rates higher than 90\% (UNESCO, 2012). Still, what we know about Latin American basic literacy rates varies significantly from one country to another, and "official rates are based on highly variable data, including selfreport, other report, and the completion of a short literacy task" (Bartlett, López, Mein, \& Valdiviezo, 2011, p. 177). According to UNESCO (2012), basic literacy inequalities persist throughout the region. Haiti, Guatemala, Nicaragua, Honduras, El Salvador, and the Dominican Republic maintain unusually high percentages of people deemed illiterate. Furthermore, they do not include literacy rates in non-dominant languages, and "statistical data confirm that indigenous youth, in particular, are affected by illiteracy, poverty, and social exclusion” (Bartlett, et al., 2011, p. 177).
Misconceptions about literacy have led to neglecting both adult and youth literacies within national and international agendas, particularly in developing countries (Torres, 2006). In the late 1980's the World Bank recommended not investing in adult literacy based on the idea that adult literacy in developing countries was unviable due to scarce resources, the need to prioritize children's education and primary school, and the low cost-effectiveness of adult literacy programs (Torres, 2006). Although the World Bank rectified this position at the beginning of the $21^{\text {st }}$ century, announcing a goal of ensuring literacy for all in order to create literate families, communities and societies, currently, basic literacy does not guarantee better income or employment in Latin America. Advanced literacy and other skills are required in well-paid jobs, and short-term programs are not sufficient to develop those skills (Torres, 2006).

Although primary education is almost universal in Latin America, enrollment in secondary education is low and there are high dropout rates. Furthermore, the consensus on public pre-K to 12 education in Latin America is that "although more students are studying longer, the quality of that education is insufficient" (Bartlett, et al., 2011, p. 180). For example, in Colombia, the socioeconomic distribution of public and private schools is such that $95 \%$ of the students in the highest socioeconomic level study in private schools, while $85 \%$ of the students in the lowest socioeconomic level study in public schools (Ministerio de Educación Nacional [MEN], 2014). This fact has sociocultural implications because private education is considered a superior good (Sarmiento, 2010).

In contrast, at the higher education level, the situation in the region is slightly different. According to Quacquarelli Symonds (QS), the highestranked university in Latin America, Universidad de Buenos Aires, is public, and from the list of the twelve best universities in the region, most are public institutions (QS World University Rankings, 2018). However, in spite of the high quality of 
some public universities, the region has lower enrollment percentages compared to global trends. In 2011 , nearly $43 \%$ of the population had access to higher education in most Latin American countries, compared to $57 \%$ in Ireland and more than $80 \%$ in the U.S., Finland, and Korea. The percentage range is heterogeneous from country to country: While enrollment rates were at more than $70 \%$ in Argentina, Cuba, and Venezuela, they were less than $30 \%$ in Mexico, El Salvador, and Honduras (OIT, 2013). In addition, in 2005 , only nearly $45 \%$ of those who accessed higher education finished their studies. This means that the region had dropout rates of more than $50 \%$. Although the rates were similar in public and private universities, they affected mostly young people from low-income families (González, 2006).

Some of the main problems in higher education are quality and equity in access. According to Altbach, Reisberg, and Rumbley (2009), "geography, unequal distribution of wealth and resources all contribute to the disadvantage of certain population groups. Participation tends to be below national average for populations living in remote or rural areas and for indigenous groups" (p. vii). For Torres (2009), issues of quality and equity are "related-in this order of importance-to (a) socioeconomic condition, (b) zone of residence (urban-rural), (c) ethnic identity, and (d) gender, as confirmed by numerous studies and evaluations in the region" (p. 6).

Furthermore, most Latin American youth face additional social problems. For example, after the cessation of Sendero Luminoso, an insurgent guerilla organization in Peru, the "main factors for the involvement of youth in violence [were] the lack of education, [and] unemployment" (Bartlett, et al., 2011, p. 188). In other countries affected by armed conflicts, such as Colombia, a significant number of young people are militants in illegal armed groups. In Colombia, between 8,000 and 14,000 youths worked for illegal groups in 2012 (Social Watch, 2012). Young people in the region are also victims of criminal violence or juvenile delinquency and aggression (Briceño-León, 2007).

Although affirmative action policies have been implemented in order to include young people from minority populations and less privileged areas of society in higher education, they are not enough. Policies have used mechanisms such as economic support for low-income students, special admission for minority groups, and special courses to address the needs of specific populations. However, these initiatives only cover a small amount of people, and they do not include long-term support focused on equitable results beyond basic accessibility (Chiroleu, 2009). Some of the critiques of policy initiatives in the region point at "their mainly rhetorical character; actual practice continues to perpetuate grave social inequalities and exclusion of historically underserved populations" (Bartlett, et al., 2011, p. 193). As such, academic literacy practices in higher education are often strongly bound to the socio-political contexts where students live and the communities where universities are embedded.

\section{Academic Literacies in Latin America}

I analyzed research literature on academic literacies in Latin American higher education from 2000 to 2017 , focusing on three models proposed by Lea and Street (2006): (1) the study skills model, (2) the academic socialization model, and (3) the critical sociocultural model. These models are not mutually exclusive, but they served as an analytical tool to look at the main trends in research on academic literacies.

\section{The Study Skills Model in Latin America}

According to Lea and Street (2006), "the study skills model is concerned with the use of written language at the surface level, and concentrates upon teaching students formal features of language; for example, sentence structure, grammar, and punctuation" (p. 369). This model is grounded in the autonomous model of literacy, which considers literacy as a set of stable, discrete, internally 
uniform, neutral cognitive skills (Horner, 2013; Street, 1999). In higher education, the autonomous model has been connected to the classic essay-text approach that privileges the production of normative and canonical texts.

As Kalman and Street (2013) recognize, "in Latin America an idea that has dominated the official discourses for decades, if not more, is that reading and writing are singular, neutral, and objective skills that are learned through a progression of ordered exercises and then transferable to any situation" (p. 1). Therefore, the study skills model has pervaded all areas and levels of education, including higher education. Most research studies under this frame analyze particular experiences or propose specific methodologies to address reading and writing instruction in college as a set of fixable skills students need to acquire to be academically successful.

At the beginning of the $21^{\text {st }}$ century, most research focused on diagnosing what university students and professors could not do from a deficit perspective, and there was an emphasis on the development of communicative competence from a pragmatic perspective (Carlino, 2013). These studies usually aimed to diagnose students' ability to comprehend academic readings and write academic texts with an emphasis on structure, grammar, and formal aspects of language, in order to propose strategies to improve these skills. They have usually rested on the premises that written products made by college students have low quality, instructors do not know how to improve these deficiencies, and there is a divorce between written practice and the appropriation of scientific knowledge (González \& Vega, 2010). Scholars under this perspective assume a need to identify the genres students consume in formal educational settings, a cognitive approach on learning and knowledge appropriation, and the development of communicative competence.

From this perspective, writing is conceived as a cognitive and communicative process (pre-writing, writing, and post-writing) used to develop critical thinking skills through interpretation and composition; and class is conceived as a space for the development of metacognition (Goyes \& Klein, 2012). There has also been an emphasis on argumentation as a privileged genre across all contexts in college academic practices. Scholars have noted that some of the challenges students face when composing argumentative texts include lack of creativity when constructing an argument, lack of evidence when supporting a thesis, lack of organization and planning, and deficiencies in paragraph construction. As a result, they propose pedagogic strategies from a psycholinguistic perspective (Goyes \& Klein, 2012).

Another area of analysis of academic reading and writing in higher education is the production of knowledge in undergraduate research. Even though incipient, this line of research is a topic worthy of analysis in countries where undergraduate students are required to write a thesis. Narváez (2009) analyzed the literacy practices of undergraduate novice researchers and observed the challenges they face in Colombia.

Regarding assessment, the Second Regional Comparative and Exploratory Study (SERCE) sponsored by UNESCO published a comprehensive report titled Escritura: Un estudio de las habilidades de los estudiantes de América Latina y el Caribe. In this report, Atorresi (2010) proposed that the assessment of writing artifacts should contribute to the process of constructing the text (coherence, cohesion, and adequacy) and guide students to participate in their learning processes. This long-term exercise aims to foster motivation, auto-regulation, and auto-criticism as teachers recognize the specific learning stages of their students.

The study skills model in Latin America has been centered on the development of writing skills and communicative competences in college students from the cognitive, psycholinguistic, and linguistic perspectives. Research studies have focused on the diagnosis of deficiencies in students and 
professors and the proposal of pedagogic strategies for classroom instruction. From an autonomous perspective of literacy, academic literacies are considered to be universal, independent, cognitive, and communicative.

\section{The Academic Socialization Model in Latin America}

In the last decade, there was a shift in the region towards the academic socialization model, which recognizes "that subject areas and disciplines use different genres and discourses to construct knowledge in particular ways" (Bazerman [1988] and Berkenkotter \& Huckin [1995] as cited in Lea \& Street, 2006, p. 369). This model includes approaches such as the genre approach, writing in the disciplines (WID), and writing across the curriculum (WAC).

At the beginning of the $21^{\text {st }}$ century there was much debate about the inclusion of academic literacies in the formal curriculum in higher education. While some authors warned about the risk of teaching reading and writing in college as a remedial solution to repair the gaps of secondary education (Marín, 2006; Murillo, 2010), another group of scholars held that reading and writing should be taught at college in the particular ways that are expected for that academic level and for each particular discipline (Carlino, 2003; 2004).

The rationale behind supporting the teaching of academic literacies in college from an academic socialization point of view is that primary and secondary school too often do not prepare students for the literate culture of tertiary education (Vázquez, 2007), and the disciplines have specific ways to address academic literacies (Carlino, 2005; Narváez \& Cadena, 2008; Peña, 2008).

In 2004, a research team headed by Carlino developed a research plan that included the study of assumptions and practices surrounding reading and writing in different subject areas that included interviews with university students and professors, surveys of professors in different disciplines, and classroom observations (Carlino, 2013). These scholars started a research tradition on learning to read and write in the disciplines grounded in the WAC and teaching writing in context methods.

Because of this movement, WAC perspectives were increasingly used as the theoretical framework for the study of academic writing, with an emphasis on the pedagogical processes involved in academic reading from psycho-cognitive and discursive semiotics perspectives (Murillo, 2012). Based on the premises of situated learning and reading and writing as social practices, Carlino proposed a shift to the process of academic acculturation, or academic socialization. The current debate in the region is not whether reading and writing should be taught at the university level, but how and where they should be taught, and who should oversee it (Carlino, 2013). Some still defend a study skills model, while others insist on the approach of teaching in context and across the curriculum. Within the socialization model, academic literacy is conceptualized as the teaching process carried out (or not) to favor students' access to the different written cultures of the disciplines (Carlino, 2013, p. 370).

As of 2018, most Latin American universities have partially included academic literacies as part of the formal curriculum. In the universities that offer academic literacy courses at the beginning of their undergraduate programs, they often assume different names but have similar objectives (Murillo, 2010). In these classes, some of the preferred instructional strategies are project-based methodologies and seminars or workshops that include writing protocols; argumentative writing also plays an important role in developing writing skills for the disciplines.

However, few universities have fully implemented WAC or WID programs (Murillo, 2010; Narváez \& Cadena, 2008) and others are in the process of creating writing centers, professional development initiatives, or teaching and learning centers (Ramos $\&$ Nieto, 2012). To describe the writing programs 
in Latin America, a project entitled Iniciativas de Lectura y Escritura en la Educación Superior en América Latina (ILEES) aimed to "map comprehensively the development of writing in higher education in Latin America by researching its practice sites and research efforts" (ILEES, 2018). The map describes several programs that include academic writing classes, writing centers, and teaching and learning centers.

Another branch of research into the academic socialization model is a socio-cognitive and discursive approach to academic literacy. According to Parodi (2010b), "empirical findings based on various approaches have documented the importance of corpus-based analysis as a way to advance and describe in detail the variation across disciplines and across genres" (p. 8). From a discourse and corpus linguistics approach, these studies aim to describe discourse genres used in university and professional settings across disciplines. Under this perspective, grammar is a central component in teaching and learning a language, even though it does not guarantee the development of expert communicative competence in specialized disciplinary genres. There is therefore a need to design pedagogic materials based on the empirical description of how language works in specific academic and professional contexts (Parodi, 2010a). Other studies have also investigated professors' reading and writing practices in disciplines (Ramos \& Nieto, 2012), the writing skills and practices of professors and students in higher education (Gutiérrez \& Flórez, 2011), and professional development programs for university professors and instructors (Narváez, Cadena \& Calle, 2009). Most authors used ethnographic research, participatory action research, and case study design.

The academic socialization model has also been used to study the comparison between the academic literacy practices in secondary and tertiary education. For instance, Fernández and Carlino (2010) conducted a qualitative study on reading and writing practices in the transition from secondary to higher education. They found that there was a significant difference between the reading and writing practices promoted in secondary school and those used in college, concluding that universities must find mechanisms to incorporate new knowledge and skills. According to Guadalupe López-Bonilla (2013), a pedagogic basic skills approach still prevails in secondary education in the region. Consequently, there is a need to close the gap between school and college, so that students who access higher education have more opportunities to appropriate knowledge.

In conclusion, among academic socialization scholars there is a theoretical agreement that academic literacy practices are different among disciplinary communities and between secondary and higher education, with higher education demanding new forms of communication that require more sophisticated reading, writing and oral expression tasks (Carrasco, Encinas, Castro, \& López, 2013). The academic socialization model has shifted assumptions about academic literacy in Latin America towards a disciplinary comprehension of literacy practices and the formulation of pedagogic strategies across a curriculum. In this context, research studies have focused on the analysis and description of disciplinary genres, professors and students' literacy practices in the disciplines, and the transition from secondary school to college. Scholars in the socialization model share the perspective that students need to be acculturated to the academic culture in order to be academically successful.

\section{The Critical Sociocultural Model in Latin America}

The critical sociocultural model is based on the perspective of literacy as a social practice (Street, 2003) that challenges deficit approaches and assumes that literacy in academic contexts is more than individual and disciplinary activities. This perspective "is concerned with meaning making, identity, power, and authority, and foregrounds the institutional nature of what counts as knowledge in any particular academic context" (Lea \& Street, 2006, p. 369). Scholars in this model consider literacy practices in academic contexts to be situated in nuanced, 
complex and dynamic sociopolitical contexts mediated by power relations.

In Latin America, research under this perspective is emergent. Studies on academic literacies are becoming more concerned with the ideological character of literacy and the sociopolitical contexts around such practices. The academic literacies model fosters the use of anthropological and sociological research methods to allow for comprehension of the complex contexts in which literacy as a social practice is interwoven with other sociocultural phenomena (see Marinho, 2010, 2013; Zavala, 2010; 2018).

According to Kalman and Street (2013), "there is a growing research community of established and new scholars located in Latin American universities and research institutions who interact with colleagues from abroad and who together collectively question this view [the autonomous model of literacy]" (p. 1). In recent years in Brazil, a group of scholars investigated academic literacy practices at the university level from an ideological perspective.

For instance, Marildes Marinho (2013) analyzed the admission of traditional peoples-indigenous and native peoples - to a Brazilian university using the New Literacy Studies, social semiotics, and French literacy studies frameworks. Marinho analyzed the dominant literacy practices at the university and the resistance of those who do not speak the mainstream dialect. Marinho found that Xacriabá indigenous people recognized how writing became part of their social organization and the tensions they faced because of their oral tradition. In another article, Marinho (2010) analyzed the written production conditions of students in an undergraduate course. From a critical sociocultural perspective, she concluded that

the commitment of the university with teaching and learningacademicwriting requires research [...] about the foundations and strategies that allow us to rebuild the principles and beliefs that have contributed to the construction of students' relation with academic literacy practices often considered 'shy', 'deficient', 'inadequate', and 'tense' (p. 363).
In addition, "ethnographic studies of literacy suggest that indigenous and immigrant youth often have to contend with various forms of xenophobia and racism in their schools" (Bartlett, et al., 2011, p. 197).

In another research line, academic literacy is connected to ideology, identity, and social change. As Harvey (2009) stated, "studying academic literacy in all its complexity requires us to accept that we face a social practice in which disciplinary ideologies, thinking frames, and language varieties converge" (p. 628). From a socio-critical approach, scholars have studied academic literacy in secondary education from the students' perspectives (López-Bonilla, Tinajero, \& Pérez, 2006), teachers' identities (López-Bonilla, 2006), and curricular reform (Tinajero, López-Bonilla, \& Pérez, 2007).

This scenario imposes challenges on institutions of higher education. They not only need to improve college admission opportunities, but also equitable access to academic literacies without detriment to the students' cultural identities. The work on critical literacy led by Latin American scholars Walkyria Monte Mór and Lynn Mario Menezes de Souza has laid the groundwork for diverse epistemological endeavors in the region (Trigos-Carrillo \& Rogers, 2017). In particular, the critical sociocultural model offers a framework for studying the sociopolitical contexts in which academic literacy practices occur, the possibility to value other forms of literacy, the potential to question and resist dominant literacies and ideals about what it means to be academically successful, and the discussion of issues of access in terms of the social identities people develop when they are part of a university community. In this respect, much research remains to be done in Latin American higher education.

\section{Towards a Critical Sociocultural Perspective on Academic Literacies}

Scholars who embrace the socialization model in Latin America have challenged the autonomous perspective of literacy by considering the different 
forms in which literacy practices and genres change across disciplines. The concept of literacy as a social practice has been adopted to understand professional and academic disciplinary contexts. As a result, universities in Latin America have created programs to support WAC, writing centers, and courses aligned with the principles of the socialization model.

This model has been useful for changing traditional practices in academic literacies in higher education, and the work scholars do under this perspective is important and should continue. However, I would like to invite scholars interested in the sociopolitical and ideological dimensions of education to consider a critical sociocultural perspective to academic literacies. One of the shortcomings of the academic socialization model is that dominant discourses in academia remain unquestioned and uncontested (Gee, 2007). The assumption perseveres that students need to be socialized and acculturated into academic genres without consideration or value of the local literacy practices that students carry out in their communities and other settings outside of school. An alternative perspective should consider broader sociopolitical contexts in which academic literacy practices take place, and the challenges and opportunities students face outside the classroom, or a broader understanding of the concept of literacy as a social practice (Street, 2003).

This framework offers unique opportunities to challenge dominant and naturalized discourses and practices (Barton, 2013). Particularly in Latin America, in-depth, situated case studies have provided a rich understanding of the ways social institutions address issues of power, domination, race, and social class through literacy practices. In our complex regional context, studies that consider social, political, and institutional dimensions of learning are needed.

Some horizons for future research include comparative analysis across different countries and sociopolitical contexts in Latin America (i.e., the distinction between urban and rural education); studies in Latin American countries that have not been the focus of attention so far; work with minority groups in higher education; research studies that include the analysis of issues of power, race, and social class in academic literacy practices; the consideration of broader global socioeconomic dynamics as well as a deeper understanding of local literacies; and more studies in new media literacy and the use of new technologies in higher education from a critical perspective. We also need to strengthen the relationship among the region's higher education scholars and institutions in order to establish a stronger presence in the global context of literacy research.

Finally, this call to assume a critical sociocultural perspective on academic literacies in Latin America intends to broaden the current state of research and complement other research efforts. After more than 40 years of Freire's project in critical pedagogy, it is worrisome that issues of power lie outside the scope of most research in academic literacies in higher education.

In a region with deep sociopolitical problems, literacy research needs to acknowledge the role of power, domination, and value in issues of access and identity construction. When students from diverse linguistic, cultural, ethnic, and socioeconomic backgrounds access higher education, they bring social resources and identities that university communities should not ignore. In a scenario where education no longer guarantees better social and economic opportunities, scholars have to rethink their comprehension of how youth engage with multiple literacies in and out of academic contexts in order to generate culturally sustaining pedagogies (Paris, 2012).

\section{References}

Archive of the Indigenous Languages of Latin America (AILLA) (2014). The Indigenous Languages of Latin America. University of Texas. Retrieved from http://www.ailla.utexas.org/site/lg_about.html 
Altbach, P., Reisberg, L. \& Rumbley, L. (2009). UNESCO Report: Trends in Global Higher Education: Tracking an Academic Revolution. UNESCO 2009 World Conference on Higher Education, UNESCO, France.

Atorresi, A. (2010). Escritura: Un estudio de las habilidades de los estudiantes de América Latina y el Caribe. LLECE/OREALC/UNESCO, Santiago, Chile.

Bartlett, L., López, D., Mein, E. \& Valdiviezo, L. (2011). Adolescent Literacies in Latin America and the Caribbean. Review of Research in Education, 35, 174207.https://doi.org/10.3102/0091732X10383210

Barton, D. (2013). Afterword. In Kalman, J. \& Street, B. (Eds.), Literacy and Numeracy in Latin America. Local Perspectives and Beyond (pp. 214-218). New York: Routledge.

Briceño-León, R. (2007). Sociología de la violencia en América Latina. Ciudadanías y violencias (Vol. 3), FLACSO, Quito, Ecuador.

Carlino, P. (2003). Alfabetización académica: un cambio necesario, algunas alternativas posibles. Educere, 6(20), 409-420.

Carlino, P. (2004). De qué modo incentivar en nuestras instituciones la responsabilidad compartida por cómo se lee y se escribe en la universidad/IFD? I Congreso Internacional Educación, Lenguaje y Sociedad: Tensiones Educativas en América Latina, Universidad Nacional de la Pampa, Santa Rosa, Argentina, July $1-3,2004$.

Carlino, P. (2005). Escribir, leer y aprender en la Universidad. Fondo de Cultura Económica, Buenos Aires, Argentina.

Carlino, P. (2013). Alfabetización académica diez años después. Revista Mexicana de Investigación Educativa, 18(57), 355-381.

Carrasco Altamirano, A., Encinas Prudencio, M., Castro Azuara, M., \& López Bonilla, G. (2013). Lectura y escritura académica en la educación media superior y superior. Revista Mexicana de Investigación Educativa, 18(57), 349-354.

Comisión Económica para América Latina y el Caribe (CEPAL), United Nations (2000). Juventud, población y desarrollo en América Latina y el Caribe: Problemas, oportunidades y desafios. Santiago de Chile: CEPAL.

Comisión Económica para América Latina y el Caribe (CEPAL), United Nations (2014). Estadisticas e Indicadores. Comisión Económica para América Latina y el Caribe. Retrieved from http://estadisticas.cepal.org/cepalstat/
WEB CEPALSTAT/estadisticasIndicadores. asp?string busqueda $=$ poblacion + por + edad

Chiroleu, A. (2009). Políticas públicas de inclusión en la educación superior: Los casos de $\mathrm{Ar}$ gentina y Brasil. Pro-Posiçôes, v. 20, 2(59), Campinas, pp. 141-166. https://doi.org/10.1590/ $\underline{\text { S0103-73072009000200010 }}$

Cunningham, W., McGinnis, L., García Verdú, C. T., \& Dorte, V. (2008). Youth at risk in Latin America and the Caribbean: Understanding the causes, realizing the potential. Washington, DC: World Bank. https://doi.org/10.1596/978-0-8213-7520-4

Dudziak, E. A. (2007). Information Literacy and Lifelong LearninginLatin America:thechallengetobuildsocial sustainability. Information development, 23(1), 4347. https://doi.org/10.1177/02666666907075630

Fernández, G. \& Carlino, P. (2010). ¿En qué se diferencian las prácticas de lectura y escritura de la Universidad y las de la escuela secundaria? Lectura y Vida. Revista Latinoamericana de Lectura, 31(1), 6-19.

Fischer, A., \& Dionísio, M. (2011). Perspectivas sobre letramento (s) no ensino superior: objetos de estudo em pesquisas acadêmicas. Atos de pesquisa em Educação, 6(1), 79-93.

Gee, J. P. (2007). Social linguistics and literacies. New York: Routledge.

González, B. \& Vega, V. (2010). Prácticas de lectura y escritura en la universidad. El caso de cinco asignaturas de la universidad Sergio Arboleda. Bogotá: Universidad Sergio Arboleda.

González, L. (2006). Repitencia y deserción universitaria. Informe sobre la educación superior en América Latina y el Caribe 200-2005, IESALC-UNESCO, Caracas, Venezuela, pp. 56-170.

Goyes, A. \& Klein, I. (2012). Alcances, limitaciones y retos de la escritura en la Universidad (Dos casos: Colombia y Argentina). En Laco, L., Natale, L., \& Ávila, M. (Eds.), La lectura y la escritura en la formación académica, docente y profesional. Pacheco, Argentina: edUTecNe.

Gutiérrez, M. \& Flórez, R. (2011). Enseñar a escribir en la universidad: saberes y prácticas de docentes y estudiantes universitarios. Revista Magis, 4(7), pp. 137-168.

Harvey, A. (2009). Acerca de la alfabetización académica y sus manifestaciones discursivas. In M. Shiro, P. Bentivoglio, \& F. D. Erlich (Eds.), Haciendo discurso. Homenaje a Adriana Bolivar (pp. 627-645). Caracas, Venezuela: Universidad Central de Venezuela. 
Holm-Nielsen, L. B., Thorn, K., Brunner, J. J., \& Balán, J. (2005). Regional and international challenges to higher education in Latin America. Higher Education in Latin America, 39.

Horner, B. (2013). Ideologies of Literacy, "Academic Literacies," and Composition Studies. Literacy in Composition Studies, 1(1), 1-9. https://doi. org/10.21623/1.1.1.2

Iniciativas de Lectura y Escritura en la Educación Superior en América Latina (ILEES) (2014). The ILEES Project: Towards a Comprehensive Map of Writing in Higher Education in Latin America. Conference on College Composition and Communication and University of California, Santa Barbara. Retrieved from http://english.ilees.org

Kalman, J. \& Street, B. (Eds.). (2013). Literacy and Numeracy in Latin America. Local Perspectives and Beyond. New York: Routledge.

Lea, M. R., \& Street, B. V. (2006). The "academic literacies" model: Theory and applications. Theory into practice, 45(4), 368-377. https://doi.org/10.1207/ s15430421 tip4504_11

Lee, M. (2010). Lenguas indígenas y políticas del lenguaje en América Latina - con especial atención a Paraguay-. Revista de Estudios Literarios, 45. Retrieved from http://webs.ucm.es/info/especulo/numero45/lengindi.html

López-Bonilla, G. (2006). Ser maestro en el bachillerato: Creencias, identidades y discursos de maestros en torno a las prácticas de literacidad. Perfiles Educativos, $28,40-67$.

López-Bonilla, G. (2013). Prácticas disciplinares, prácticas escolares: qué son las disciplinas académicas y cómo se relacionan con la educación formal en las ciencias y en las humanidades. Revista Mexicana de Investigación Educativa, 18(57), 383-412.

López-Bonilla, G., Tinajero, G., \& Pérez, C. (2006). Jóvenes, currículo y competencia literaria. Revista Electrónica de Investigación Educativa, 8, 1-24.

Marín, M., (2006). Alfabetización académica temprana. Lectura y Vida, 4, 30-38.

Marinho, M. (2010). A escrita nas práticas de letramento acadêmico. Revista Brasileira de Linguistica Aplicada. Belo Horizonte, 10(2), 363-386. https://doi. org/10.1590/S1984-63982010000200005

Marinho, M. (2013). The local and the global in literacy practices in "traditional communities." In Kalman, J. \& Street, B. (Eds.), Literacy and Numeracy in Latin
America. Local Perspectives and Beyond (pp. 19-37). New York: Routledge.

Ministerio de Educación Nacional, (2014). Estadísticas de Educación Básica y Media. Retrieved from http://menweb.mineducacion. gov.co/seguimiento/estadisticas/principal. php? consulta $=$ mat total $\&$ nivel $=2$

Mora, R. (2012). Literacidad y el aprendizaje de lenguas: Nuevas formas de entender los mundos y las palabras de nuestros estudiantes. Revista Internacional Magisterio, 58, 52-56.

Murillo, M. (2012). El estado de la investigación en la enseñanza de la lectura y la escritura en la universidad colombiana. EIDOS, 5, 47-96.

Murillo, M. E. (2010). La actividad discursiva en la construcción del conocimiento en una situación de escritura en las disciplinas: los géneros académicos en la universidad. Doctoral Dissertation. Doctorado en Didáctica de la Lengua y la Literatura. Universidad Autónoma de Barcelona.

Narváez C., E. (2009). Dimensionar las características de la escritura académica y anticipar su demanda: un caso en la formación de estudiantes de pregrado. Memorias del III Encuentro Nacional y II Internacional de Lectura y Escritura, Bogotá.

Narváez, E. \& Cadena, S. (Comp.). (2008). Los desafíos de la lectura y la escritura en la educación superior: caminos posibles. Cali, Colombia: Universidad Autónoma de Occidente.

Narváez, E., Cadena, S. \& Calle, B. E. (2009). Una práctica de lectura académica en una experiencia de formación de docentes universitarios. Magis. Revista Internacional de Investigación en Educación, 1(2).

Organización Internacional del Trabajo (OIT) (2013). Trabajo decente y juventud en América Latina. Organización Internacional del Trabajo, Report. Retrieved from http://www.ilo.org/wcmsp5/groups/ public/---americas/---ro-lima/documents/publication/wcms 235577.pdf

Paris, D. (2012). Culturally sustaining pedagogy: A needed change in stance, terminology, and practice. Educational Researcher, 41(3), 93-97. https://doi. org/10.3102/0013189X12441244

Parodi, G. (Ed.). (2010a). Alfabetización académica y profesional en el siglo XXI: leer y escribir desde las disciplinas. Santiago de Chile: Ariel.

Parodi, G. (Ed.). (2010b). Academic and professional discourse genres in Spanish (vol. 40). Amsterdam: John Benjamins Publishing. 
Peña, L. B. (2008). La competencia oral y escrita en la educación superior. Colombia: MEN. Retrieved from http://www.mineducacion.gov.co/1621/articles-189357_archivo_pdf_comunicacion.pdf

QS World University Rankings (2018). QS Latin American University Rankings 2018. Retrieved from https:// www.topuniversities.com/university-rankings/ world-university-rankings/2018

Ramos, L. \& Nieto, L. (2012). Prácticas de lectura y escritura en la educación superior. In J. C. Arboleda (Ed.), Textualidades, diversidad y evaluación (pp. 4362). Colombia: Red Iberoamericana de Pedagogía, Redipe.

Sarmiento, A. (2010). Situación de la educación en Colombia: Preescolar, Básica, Media y Superior (3ª. ed.). Bogotá: Proyecto Educación Compromiso de Todos.

Social Watch (2012). Colombia: Persiste el reclutamiento forzado de niños, niñas y adolescentes. Retrieved from http://www.socialwatch.org/es/node/14315.

Street, B. (1999). Academic literacies. In C. Jones, J. Turner, and B. Street (Eds.), Students writing in the university: Cultural and epistemological issues, (pp. 193-227). Amsterdam: John Benjamins.

Street, B. (2003). What's "new" in New Literacy Studies? Critical approaches to literacy in theory and practice. Current issues in comparative education, 5(2), 77-91.

Tinajero, G., López-Bonilla, G., \& Pérez, C. (2007). Cambio curricular en el bachillerato tecnológico mexicano: El caso de la disciplina de ciencia, tecnología, sociedad y valores. Archivos Analíticos de Politicas Educativas, 15, 1-25.
Torres, R. M. (2006). Alfabetización y aprendizaje a lo largo de toda la vida. Revista Interamericana de Educación de Adultos, (1), Organización de Estados Iberoamericanos (OEI).

Torres, R. M. (2009). From literacy to lifelong learning: Trends, issues and challenges in youth and adult education in Latin America and the Caribbean Regional Synthesis Report. UNESCO-UIL, CONFINTEA VI, Hamburg, Germany.

Trigos-Carrillo, L., \& Rogers, R. (2017). Latin American influences on multiliteracies: From epistemological diversity to cognitive justice. Literacy Research: Theory, Method, and Practice, 66(1), 373-388. https:// doi.org/10.1177/2381336917718500

United Nations Organization for Education, Science and Culture (UNESCO) (2012, September). Adult and young literacies. UNESCO Institute of Statistics Fact Sheet No. 20. Retrieved from http://www.uis. unesco.org/literacy/Documents/fs20-literacy-day2012-en-v3.pdf

Vázquez, A. (2007). ¿Alfabetización en la Universidad? Rivarosa, A. (Comp.), Estaciones para el debate. Un mapa de diálogo con la cultura universitaria. Río $\mathrm{Cu}-$ arto: Imprenta de la UNRC.

Zavala, V. (2010). Quem está dizendo isso?: letramento acadêmico, identidade e poder na educação superior. Letramentos: rupturas, deslocamentos e repercussões de pesquisa em linguistica aplicada. Campinas, SP: Mercado de Letras, 71-95.

Zavala, V. (2018). Language as social practice: deconstructing boundaries in intercultural bilingual education. Trabalhos em Linguistica Aplicada, 57(3), 1313-1338. https://doi.org/10.1590/010318138653255423542

How to reference this article: Trigos-Carrillo, L. (2019). A Critical Sociocultural Perspective to Academic Literacies in Latin America. Íkala, Revista de Lenguaje y Cultura, 24(1), 13-26. Dor: 10.17533 / udea.ikala.v24n01a10 